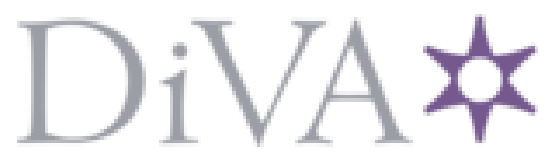

http://www.diva-portal.org

This is the published version of a paper published in Ecology.

Citation for the original published paper (version of record):

Wardle, D., Jonsson, M. (2014)

Long-term resilience of above- and belowground ecosystem components among contrasting ecosystems.

Ecology, 95(7): 1836-1849

Access to the published version may require subscription.

N.B. When citing this work, cite the original published paper.

Permanent link to this version:

http://urn.kb.se/resolve?urn=urn:nbn:se:umu:diva-9227 1 


\title{
Long-term resilience of above- and belowground ecosystem components among contrasting ecosystems
}

\author{
David A. Wardle ${ }^{1,3}$ and Micael Jonsson ${ }^{2}$ \\ ${ }^{1}$ Department of Forest Ecology and Management, Swedish University of Agricultural Sciences, Umeå SE90183 Sweden \\ ${ }^{2}$ Department of Ecology and Environmental Science, Umeå University, Umeå SE90187 Sweden
}

\begin{abstract}
While several studies have explored how short-term ecological responses to disturbance vary among ecosystems, experimental studies of how contrasting ecosystems recover from disturbance in the longer term are few. We performed a simple long-term experiment on each of 30 contrasting forested islands in northern Sweden that vary in size; as size decreases, time since fire increases, soil fertility and ecosystem productivity declines, and plant species diversity increases. We predicted that resilience of understory plant community properties would be greatest on the larger, more productive islands, and that this would be paralleled by greater resilience of soil biotic and abiotic properties. For each island, we applied three disturbance treatments of increasing intensity to the forest understory once in 1998, i.e., light trimming, heavy trimming, and burning; a fourth treatment was an undisturbed control. We measured recovery of the understory vascular plant community annually over the following 14 years, and at that time also assessed recovery of mosses and several belowground variables. Consistent with our predictions, vascular plant whole-community variables (total cover, species richness, diversity [Shannon's $H^{\prime}$ ], and community composition) recovered significantly more slowly on the smaller (least fertile) than the larger islands, but this difference was not substantial, and only noticeable in the most severely disturbed treatment. When an index of resilience was used, we were unable to detect effects of island size on the recovery of any property. We found that mosses and one shrub species (Empetrum hermaphroditum) recovered particularly slowly, and the higher abundance of this shrub on small islands was sufficient to explain any slower recovery of whole-ecosystem variables on those islands. Further, several belowground variables had not fully recovered from the most intense disturbance after $14 \mathrm{yr}$, and counter to our predictions, the degree of their recovery was never influenced by island size. While several studies have shown large variation among plant communities in their short-term response (notably resistance) to environmental perturbations, our results reveal that when perturbations are applied equally to highly contrasting ecosystems, differences in resilience among them in the longer term can be relatively minor, regardless of the severity of disturbance.
\end{abstract}

Key words: aboveground-belowground linkages; disturbance; ecosystem; Empetrum hermaphroditum; microbial community; nitrogen; resilience; stability.

\section{INTRODUCTION}

All natural ecosystems are subject to disturbance regimes, which impact organisms, communities, and ecosystem processes (Pickett and White 1985). Furthermore, ecosystems can differ greatly in how they respond to disturbance, both in terms of their resistance (i.e., the degree to which they remain unchanged by disturbance) and resilience (i.e., their capacity to return to a reference state over time following a perturbation; Holling 1973, Pimm 1991, Grimm and Wissel 1997). Differences among ecosystems in how they are impacted by disturbance are driven by both abiotic and biotic factors. Abiotic factors that cause varying responses

Manuscript received 30 August 2013; revised 2 December 2013; accepted 10 December 2013. Corresponding Editor: H. A. L. Henry.

${ }^{3}$ E-mail: david.wardle@slu.se among ecosystems include climate (Vicente-Serrano et al. 2013), soil fertility (Gendron and Wilson 2007), and stage of ecosystem development (Orwin et al. 2006). With regard to biotic factors, many studies have focused on how responses to disturbance are mediated by particular community-level attributes. As such, it is well recognized that differences among ecosystems in their responses are driven by the growth characteristics of the dominant plant species (Roovers et al. 2004) and the functional trait spectra of the plant community (McGillivray et al. 1995, Bernhardt-Römermann et al. 2011, Mouillot et al. 2013). Furthermore, there is a considerable body of literature on whether and how plant communities differing in diversity (primarily at the species level) stabilize ecosystem properties in terms of both their resistance and resilience to disturbance (Ives and Carpenter 2007, Cardinale et al. 2012).

Although the issue of community and ecosystem responses to disturbance has attracted considerable 
attention, we still have a limited understanding of how ecosystems differing in factors believed to influence effects of disturbance recover relative to each other over time. Several studies have explored aspects of this issue experimentally, by comparing the ecological response to disturbance treatments of communities differing in functional trait properties (McGillivray et al. 1995, Chillo et al. 2011), species diversity (Sankaran and McNaughton 1999, Pfisterer and Schmid 2002), and biogeographic location (Bernhardt-Römermann et al. 2011). However, one drawback of most of these studies is that they are inherently short-term, and have monitored responses to disturbance for only a year or two after the disturbance was applied. While such studies can accurately inform on an ecosystem's resistance to disturbance, they have limitations in understanding resilience, because communities can take at least several years, and often decades, centuries, or even millennia to fully recover (Walker and Reddell 2007). Other studies have explored the responses to disturbance observationally, by monitoring the recovery of communities after catastrophic natural disturbance events, sometimes over the order of decades (e.g., Batista and Platt 2003, Tanner and Bellingham 2006). While such studies have considerable value in understanding long-term community dynamics, they pose difficulties for assessing long-term resilience, because catastrophic disturbances usually do not occur randomly in the landscape. This makes it challenging or impossible to find appropriate undisturbed controls, and therefore to determine when the ecosystem has returned to the reference state.

All ecosystems consist of above- and belowground components, and interactions and feedbacks between them drive ecosystem processes such as biomass production, decomposition, and nutrient cycling (Wardle 2002, Freschet et al. 2013). While many experimental studies have explored how either the aboveground or belowground components respond to disturbance in isolation (Wardle 2002), surprisingly few have considered the response of both components within the same study or experiment (e.g., Wardle et al. 2000, Sørensen et al. 2008). Furthermore, those studies that have explored how both components respond to experimental disturbances have considered only short-term responses (typically a year or less), which limits comparisons of how the aboveground and belowground subsystems recover from disturbance over time. Hence, our understanding is limited of whether recovery following disturbance of the aboveground and belowground subsystems over time is coupled, or whether coupling of responses varies among ecosystems that differ in factors believed to influence recovery from disturbance.

In the present study, we focused on a group of 30 wellstudied forested lake islands in northern Sweden, each of which operates as an independent replicate ecosystem (Wardle et al. 1997, 2012). These islands differ greatly in size, with larger islands being struck by lightning more often and therefore burning more frequently. As such, the larger islands have greater soil fertility, are more productive, are dominated more by plants with traits associated with resource acquisition (as opposed to resource conservation), and have lower plant species diversity, when compared with the smaller islands (Wardle et al. 2012). In 1998 we imposed three separate disturbance treatments of increasing intensity on the forest understory of each island (along with a corresponding undisturbed control), and monitored plant community changes each year over the following $14 \mathrm{yr}$. We also measured the extent to which a suite of abiotic and biotic soil properties recovered from the disturbance treatments after $14 \mathrm{yr}$. This design enabled us to study long-term resilience of aboveground and belowground properties among contrasting ecosystems, i.e., the extent to which they recovered over $14 \mathrm{yr}$ following the perturbation.

It has been predicted that ecosystems that have a higher productivity are more stable when they are more productive, and that more productive ecosystems can recover faster from extrinsic disturbances (Hooper et al. 2005, Ives and Carpenter 2007). There is also a considerable body of literature on the relationship between species diversity and ecosystem stability (including resilience), with several studies suggesting that diversity enhances ecosystem stability (Tilman et al. 2006, Cardinale et al. 2012). In the present study, we sought to test two hypotheses. Our first hypothesis relates to the plant community data, for which we had $14 \mathrm{yr}$ of post-disturbance measurements. Here, we hypothesized that resilience to disturbance of dominant plant species and community-level properties are greatest for large islands, because they are more fertile and productive. An opposing hypothesis would be that small islands are more resilient because they have greater plant diversity. Our second hypothesis relates to data for belowground properties, which we measured once in each plot after $14 \mathrm{yr}$. There are often important feedbacks between the aboveground and belowground subsystems in terms of carbon and nutrient processes, as well as community composition (Wardle 2002). Therefore, we hypothesized that after $14 \mathrm{yr}$, belowground properties of disturbed plots would have shown a greater recovery on the larger, more productive islands, because they would parallel the recovery patterns predicted for aboveground community properties. Addressing these hypotheses in combination is expected to aid understanding of how contrasting ecosystems recover, both aboveground and belowground, following ecological disturbances.

\section{Materials And Methods}

\section{Study system and experimental setup}

The study system consists of 30 islands in lakes Hornavan and Uddjaure in northern Sweden $\left(65^{\circ} 55^{\prime} \mathrm{N}\right.$ to $66^{\circ} 09^{\prime} \mathrm{N}, 17^{\circ} 43^{\prime} \mathrm{E}$ to $17^{\circ} 55^{\prime} \mathrm{E}$; see Plate 1$)$. The mean annual precipitation is $750 \mathrm{~mm}$, and the mean temper- 
ature is $13^{\circ} \mathrm{C}$ in July and $-14^{\circ} \mathrm{C}$ in January. All islands were formed following the retreat of land ice about 9000 $\mathrm{yr}$ ago. The only major extrinsic factor that varies among islands is the history of lightning-ignited wildfire, with larger islands having burned more frequently than smaller islands because of their larger area to intercept lightning (Wardle et al. 1997, 2003). Previous studies on these islands have shown that as they become smaller and time since fire increases, they enter a state of ecosystem retrogression (Peltzer et al. 2010), in which there is a reduction in soil fertility (notably a reduced availability of plant-available nitrogen and phosphorus), plant biomass, and ecosystem productivity, and an increase in plant species diversity (Wardle et al. 2003, 2004, 2012; Appendix A).

The islands were divided into three size classes with 10 islands per class: large ( $>1.0 \mathrm{ha})$, medium $(0.1-1.0 \mathrm{ha})$, and small $(<0.1 \mathrm{ha})$, with a mean time since last major fire of 585, 2180, and $3250 \mathrm{yr}$, respectively (Wardle et al. 2003). The use of size classes in this way enables simple statistical testing of interactive effects of island size with other factors, such as experimental treatments (e.g., Wardle and Zackrisson 2005, Gundale et al. 2010). All islands burned at least $60 \mathrm{yr}$ ago (and up to $5350 \mathrm{yr}$ ago), and so have not been subjected to differing fire disturbance regimes for several decades prior to the present study. The overstory vegetation of the island system is dominated by Pinus sylvestris, Betula pubescens, and Picea abies, which achieve their greatest relative biomass on large, medium, and small islands respectively. The ground layer vascular vegetation is dense and dominated by the dwarf shrubs Vaccinium myrtillus, V. vitis-idaea, and Empetrum hermaphroditum (which achieve their greatest relative biomass on large, medium, and small islands, respectively), and the feather mosses Hylocomium splendens and Pleurozium schreberi (which are abundant in all island size classes).

The present study was focused on the dwarf shrub and moss layer in the forest understory; this layer is responsible for over half of total net primary productivity in all island size classes (Wardle et al. 2012). On each of the 30 islands, we established four square plots on understory vegetation characteristic of that island in August 1998. These plots were always at least $80 \times 80$ $\mathrm{cm}$, but only the inner $50 \times 50 \mathrm{~cm}$ was ever measured. One of these plots was randomly assigned to each of four disturbance treatments.

Treatments consisted of (1) control, i.e., left intact; (2) light trimming (low disturbance), where all dwarf shrubs were trimmed down to the top of the live feather moss layer and removed; (3) heavy trimming (medium disturbance), where all dwarf shrubs and mosses were trimmed down to the interface between the live and dead parts of the feather moss layer and removed; and (4) burning (high disturbance), where a butane flamethrower was used to burn an area of approximately $1.5 \times 1.5$ $\mathrm{m}$ down to the upper surface of the humus layer (Schimmel and Granström 1996, Norberg et al. 1997).
Larger plots were used for this last treatment because it is impossible to reliably burn smaller plots using this approach. For two weeks prior to burning, plots were covered with small plastic tents so that they all burned equally well, regardless of weather conditions (Schimmel and Granström 1996).

Trimming disturbances were imposed over 1-12 August 1998, and burning treatments over 13-17 August 1998. Other than these single disturbances, no other disturbances were implemented at any time. The disturbances were applied equally to all islands regardless of size, and are of comparable intensity to those that can be caused by both biotic and abiotic disturbances. As such, our shrub trimming treatments created similar conditions at the patch scale as defoliation or death of ground layer ericaceous vegetation caused by disturbance agents such as foliar herbivory, pathogens, or extreme climatic events in northern Sweden (Bokhorst et al. 2009, Nordin et al. 2009). Further, the burning treatment consumed shrub and moss vegetation down to the humus layer in much the same way as occurs through wildfire in this region (Schimmel and Granström 1996). We performed this study adjacent to plots used by Wardle et al. (2003); plots were always located at similar distances from the shore regardless of island size to prevent edge and microclimatic effects from confounding the results (Wardle et al. 1997, 2003).

\section{Measurements}

For all measurements, we utilized only the inner $0.5 \times$ $0.5 \mathrm{~m}$ of the disturbed plot area, consistent with other plot-scale investigations performed on these islands (e.g., Wardle and Zackrisson 2005, Gundale et al. 2010). During 1-12 August 1998 (i.e., prior to the implementation of the disturbance treatments), and during the first two weeks of August each year from 1999 to 2012 inclusive, we measured vascular plant vegetation on each plot by using the point intercept method used by Wardle and Zackrisson (2005). For each plot, we recorded the total number of times each species present was intercepted by a total of 100 downwardly projected points located throughout the plot. This provides a measure of cover density of each species, and within species is strongly correlated with standing biomass (Wardle et al. 2003). The total amount of intercepts of all species gave a measure of total cover of that plot, which can exceed $100 \%$ if individual points intercept multiple leaves or stems. We also used these data to estimate vegetation diversity of the plot by calculating the Shannon diversity index (hereafter Shannon's $H^{\prime}$ ). In addition, total species richness in each plot was determined visually.

At the end of the experiment (2-14 August 2012), several additional measurements were made for each plot to determine the extent to which key community and ecosystem properties had recovered 14 yr postdisturbance. First, we estimated biomass of each of the two dominant moss species in each plot (H. splendens 


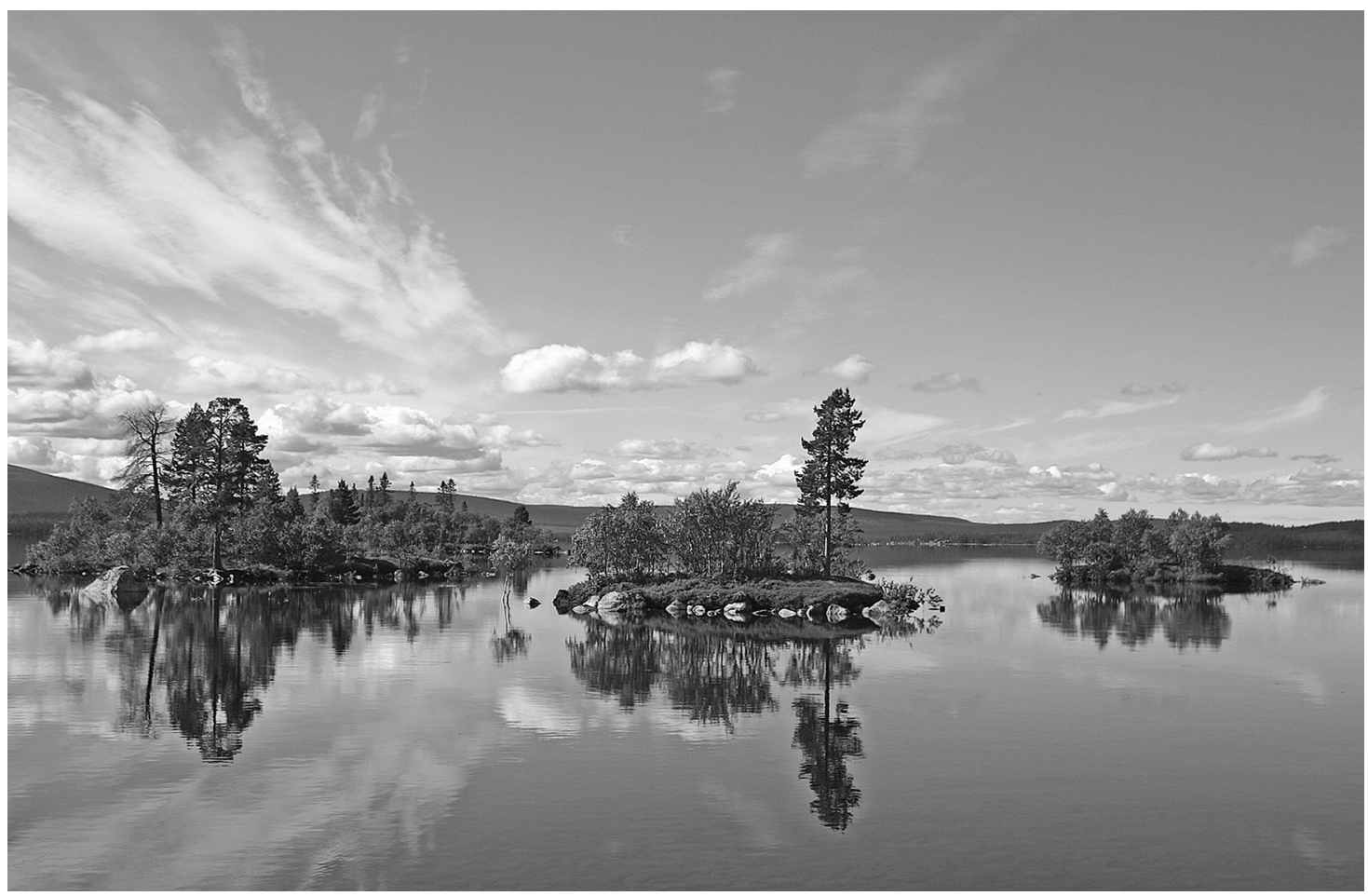

Plate 1. Islands in the study system in Lake Uddjaure, Sweden. Photo credit: M. Jonsson.

and $P$. schreberi) using the approach of Lagerström et al. (2007), which involved measuring the depth of the live moss layer of each species at each of 15 random points throughout the plot, and converting mean depth to biomass using previously established calibration equations. Furthermore, within each plot we collected approximately 30 randomly located soil cores beneath the litter layer (each $2.5 \mathrm{~cm}$ in diameter $\times 10 \mathrm{~cm}$ deep; cores consisted entirely of humus) and bulked them into a single sample for abiotic and biotic measurements. Upon collection, soils were sieved to $4 \mathrm{~mm}$ and stored at $4^{\circ} \mathrm{C}$ until further use.

Abiotic soil properties measured on a subsample of each soil sample included gravimetric moisture, $\mathrm{pH}$, and (following extraction with $1 \mathrm{~mol} / \mathrm{L} \mathrm{KCl}$ ) ammonium, nitrate, and phosphate by colorimetery on an AutoAnalyzer III (Omni Process, Solna, Sweden). Total C and $\mathrm{N}$ were measured by combustion and thermal conductivity detection using a Flash 1112 Elemental Analyzer (Thermo Scientific, Waltham, Massachusetts, USA). Total $\mathrm{P}$ was measured by combustion and dissolution of ash in $1 \mathrm{~mol} / \mathrm{L} \mathrm{H}_{2} \mathrm{SO}_{4}$, followed by phosphate detection using automated molybdate colorimetry on a Lachat Quikchem 8500 analyzer (Milwaukee, Wisconsin, USA). These data were used to calculate the ratios of $\mathrm{C}$ to $\mathrm{P}, \mathrm{C}$ to $\mathrm{N}, \mathrm{N}$ to $\mathrm{P}$, mineral $\mathrm{N}$ (ammonium + nitrate) to total N, and mineral (phosphate) $\mathrm{P}$ to total $\mathrm{P}$.
For a subsample of each soil sample, we also quantified soil microbial properties. We measured substrate-induced respiration (SIR; a relative measure of active microbial biomass) as described by Anderson and Domsch (1978) and modified by Wardle (1993). Briefly, a 3-g (dry mass) subsample of soil was amended to $150 \%$ moisture content (dry mass basis), amended with $30 \mathrm{mg}$ glucose, placed in a $130-\mathrm{mL}$ airtight vessel, and incubated at $22^{\circ} \mathrm{C}$. Evolution of $\mathrm{CO}_{2}$ between $1 \mathrm{~h}$ and $4 \mathrm{~h}$ was then determined by injecting $1-\mathrm{mL}$ subsamples of headspace gas into an ADC 2250 Gas Analyzer (ADC BioScientific, Hoddesdon, UK), and used as a measure of SIR. We also measured the composition of microbial phospholipid fatty acids (PLFAs) for assessing the microbial community by using the method of Bligh and Dyer (1959) as modified by White et al. (1979); different PLFAs represent different subsets of the soil microflora. For each soil, the abundance of each fatty acid extracted was expressed as relative $\mathrm{nmol} / \mathrm{g}$ of dry soil using standard nomenclature. The PLFAs i15:0, a15:0, i16:0, 16:1 $\omega 9,16: 1 \omega 7 \mathrm{t}$,

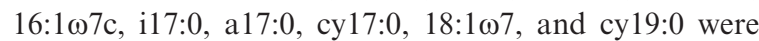
used to indicate relative bacterial biomass, the PLFA 18:206 was used as to indicate relative fungal biomass (Frostegård and Bååth 1996), and the PLFAs 10Me17:0 and 10Me18:0 were used to indicate relative actinomycete biomass (Kroppenstedt 1985). The PLFAs used for calculation of total branched PLFAs (i.e., gram positive bacteria) were i-15:0, a-15:0, i-16:0, and i-17:0, while 
those used to determine total cyclic PLFAs were cyc17:0 and cyc-19:0. The PLFA chosen to represent fungi and the sum of the PLFAs chosen to represent bacteria were used to calculate the fungal to bacterial ratio (Frostegård and Bååth 1996) for each plot.

To assess soil decomposer activity, four litter bags were placed in each plot during 1-14 August 2011, and harvested 1 yr later during 1-14 August 2012. All bags were made of $0.3-\mathrm{mm}$ mesh and enclosed $3 \mathrm{~g}$ (dry mass) of $V$. myrtillus litter; this litter had $\mathrm{N}$ and $\mathrm{P}$ concentrations of $0.58 \%$ and $0.13 \%$, respectively. Two of these bags were placed on the ground surface among the live moss layer and two were buried at $5 \mathrm{~cm}$ depth in the humus. Following harvest, the litter in the two bags at each depth was combined, and determinations made of the remaining dry mass $\left(60^{\circ} \mathrm{C}, 48 \mathrm{~h}\right)$; litter decomposition rate was determined as the percentage of mass lost.

\section{Data analysis}

We used the vascular plant data to test the first hypothesis, i.e., that larger islands were more resilient to disturbance. We used principal components analysis (PCA) to summarize the full vascular plant species cover data set across all years for all plots into fewer variables, so that treatment effects on community composition could be directly assessed over time (see Wardle et al. 2013). Before PCA was performed, all data were converted to proportions. For each community-level response variable that we measured (including the primary and secondary principal components from the PCA, i.e., PC1 and PC2), and for total cover for each of the three most abundant species ( $V$. myrtillus, V. vitisidaea, and $E$. hermaphroditum), data were analyzed by repeated measures split-plot ANOVA, with island size as the main plot factor and disturbance treatment as the within-plot factor. For all data analysis, variables were transformed as necessary to satisfy ANOVA assumptions. A significant interactive effect of disturbance treatment $\times$ island size meant that responses to disturbance varied with island size; a significant threeway interactive effect of these two factors and time meant that responses to disturbances over time varied with island size. A significant three-way interaction did not necessarily mean that the first hypothesis was supported, but a nonsignificant interaction meant that it could not be supported.

To further test the first hypothesis for each vascular plant response variable (except for ordination score values, see below), we determined the extent to which that variable had recovered from disturbance for each disturbed plot on each island, or its post-disturbance resilience $(V)$, for each of the years 1999 to 2012 inclusive. This involved calculation of the following metric (Wardle 1995)

$$
V=(2 \times D) /(D+C)-1
$$

where $D$ is the value for the disturbed plot and $C$ is the value for the corresponding undisturbed (control) plot on the same island. This index varies between -1 and +1 , and is negative or positive depending on whether the value in the disturbed plot is smaller or larger than in the control plot; a value of 0 indicates that values for both plots are the same, and that the disturbed plot has therefore fully recovered. This index is conceptually based on the resilience index of Orwin and Wardle (2004), except that the point of reference against which the disturbed plot was compared was the corresponding control plot measured at the same time, rather than the disturbed plot measured prior to the disturbance, which is preferable as the control plot may itself change over time. For each variable within each year, we tested whether responses to the three disturbed treatments differed among island size classes, by analyzing values of $V$ with a split-plot ANOVA with island size as the main plot factor and disturbance treatment as the subplot factor; when effects of factors were significant at $P=$ 0.05, post-hoc comparison of means was performed using Tukey's test. Furthermore, for each disturbance treatment within each island size class for each year, confidence intervals (with $n=10$ replicate islands) were used to determine whether $V$ was significantly different to 0 at $P=0.05,0.01$, or 0.001 . For the ordination scores, it was not possible to calculate $V$ because these scores can be either positive or negative, so we instead subtracted the score of each disturbed plot from that of the corresponding control plot from the same island (because these scores are already standardized) for that year, and values for these differences were subjected to the same data analyses as described above for the values for $V$.

We used the data collected in 2012 to test the second hypothesis, i.e., that after $14 \mathrm{yr}$, recovery belowground would be coupled to recovery aboveground. To do this, each variable measured only in 2012 (i.e., all abiotic and biotic soil variables, and moss data), was analyzed using a two-way ANOVA, with island size as the main plot factor and disturbance treatment (including control) as the subplot factor. Prior to this analysis, we summarized the microbial PLFA data into fewer variables using PCA exactly as described for the vascular plant data. A significant interaction term between island size and disturbance treatment did not necessarily mean that the second hypothesis was supported, but a nonsignificant interaction meant that it was unsupported. To further explore the second hypothesis, we calculated $V$ for each disturbed plot on each island (except for PCA scores of the PLFA data, for which differences between disturbed and control plots were used), and analyzed this data exactly as described for the vascular plant data. All data were analyzed by Statistix 8.1 (Tallahassee, Florida, USA).

\section{Results}

\section{Aboveground measurements}

For vascular plants, all variables except species richness and $\mathrm{PC} 2$ responded to the interactive effect of 

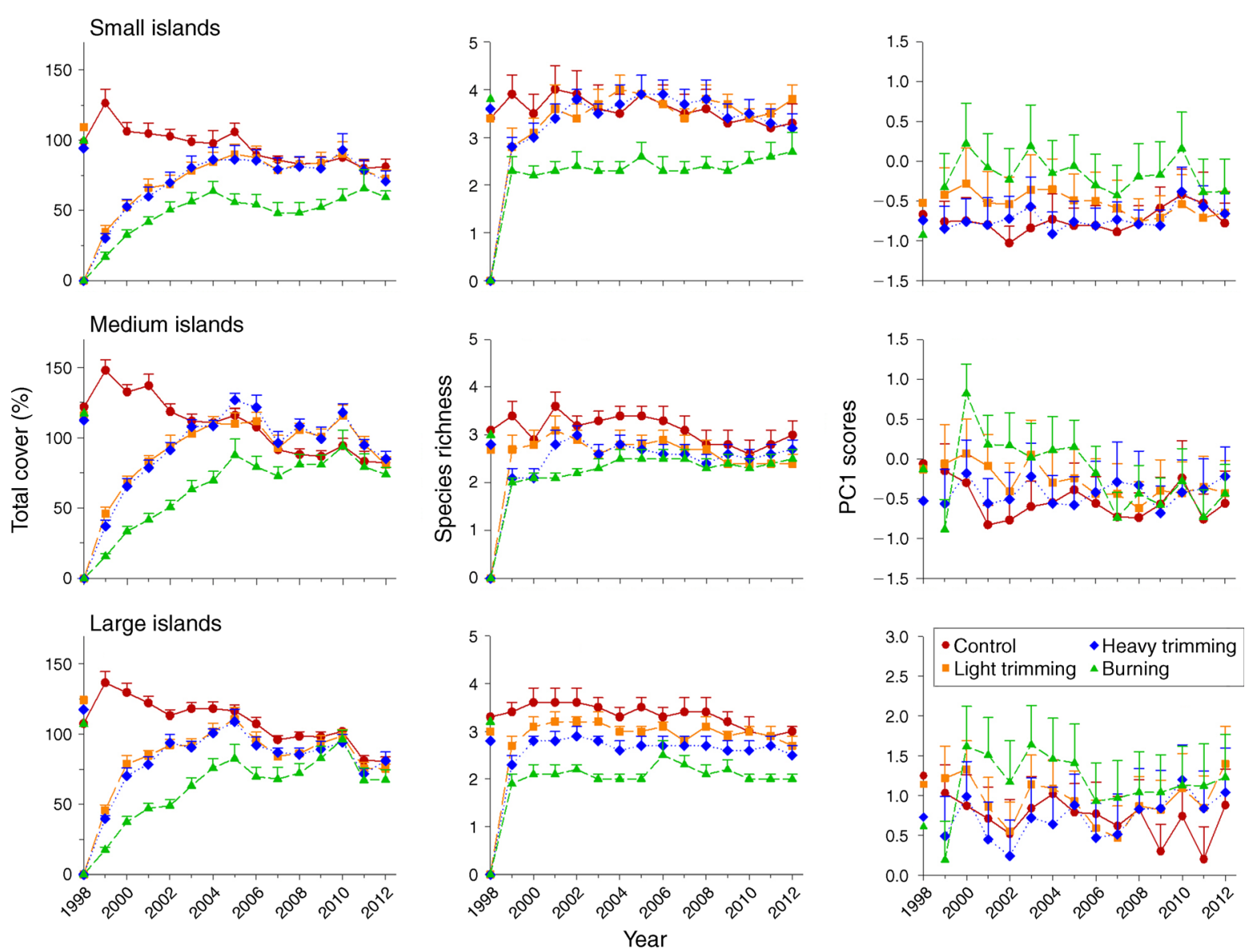

FIG. 1. Community level variables, i.e., total cover (numbers of total vegetation intercepts by 100 points), species richness, and scores for the principal ordination axis (PC1), for vascular plants in plots differing in a single disturbance applied in 1998, on small, medium, and large islands over a 14-yr period. Red circles indicate no disturbance (control); orange squares indicate disturbance by light trimming; blue diamonds indicate disturbance by heavy trimming; and green triangles indicate disturbance by burning. Symbols placed directly on the $y$-axis represent cover immediately before the disturbance was initiated, after which cover and species richness for the light trimming, heavy trimming, and burning treatments was zero. Vertical bars represent standard errors. ANOVA results are shown in Appendix C.

island size, time, and disturbance (though the response for species richness was almost significant; Appendix B), a condition that must be fulfilled for the first hypothesis to be supported. For all variables, the burned treatment recovered more slowly than did the two trimmed treatments, and the slowest recovery from burning occurred on the small islands for all variables, while the fastest recovery occurred on the medium islands for species richness and PC1 (Fig. 1) and for Shannon's $H^{\prime}$ (data not presented), in line with the first hypothesis. There were no clear effects of island size on the recovery of any community variable from trimming, which is inconsistent with the first hypothesis, except that species richness in the heavily trimmed treatment appeared to recover fastest on small islands (Fig. 1). For vascular plants, four of the five whole-community measures (i.e., total cover, species richness, PC1, PC2, but not Shannon's $H^{\prime}$ ) were directly influenced by island size, and all responded to the island size $\times$ time interactive effect (Appendix B). As such, overall total cover was least and species richness was greatest on the small islands (Fig. 1).

Calculation of the index $V$ (three representative years of which are shown in Table 1) revealed that resilience was unaffected by island size or its interaction with disturbance treatment for any whole-community variable, which is inconsistent with the first hypothesis. This index also showed that whole-community variables recovered more slowly in the burning than the trimming treatments, with total cover and species richness in the burning treatment having still not fully recovered after 14 yr (Table 1).

The three dominant vascular plant species, which comprise $>95 \%$ of the total vascular plant cover in this study, responded to the interactive effect of disturbance, time, and island size (Appendix B), consistent with the first hypothesis. As such, V. myrtillus took the most time to recover on large islands, while $V$. vitis-idaea took the 
TABLE 1. Impact of disturbance applied in 1998 on vascular plant response variables for three representative years after disturbance, i.e., 2000 (year 2), 2004 (year 6), and 2012 (year 14), and moss variables at 2012 (year 14).

\begin{tabular}{|c|c|c|c|c|c|c|}
\hline \multirow[b]{2}{*}{$\begin{array}{c}\text { Response variable } \\
\text { and year }\end{array}$} & \multicolumn{3}{|c|}{ ANOVA results } & \multicolumn{3}{|c|}{ Response to disturbance (mean $\pm \mathrm{SE}$ ) } \\
\hline & $\begin{array}{l}\text { Island } \\
\text { size }(I)\end{array}$ & $\begin{array}{l}\text { Disturbance } \\
\text { treatment }(D)\end{array}$ & $I \times D$ & Light trimming & Heavy trimming & Burning \\
\hline \multicolumn{7}{|l|}{$\begin{array}{l}\text { Total vascular plant } \\
\text { cover }\end{array}$} \\
\hline $\begin{array}{l}2000 \\
2004 \\
2012\end{array}$ & $\begin{array}{l}0.8(0.488) \\
0.3(0.769) \\
2.2(0.167)\end{array}$ & $\begin{array}{c}67.8(<0.001) \\
22.6(<0.001) \\
5.4(0.008)\end{array}$ & $\begin{array}{l}1.2(0.383) \\
0.7(0.598) \\
0.3(0.887)\end{array}$ & $\begin{array}{l}-0.304^{\mathrm{a}} \pm 0.022^{* * *} \\
-0.056^{\mathrm{a}} \pm 0.031 \\
-0.037^{\mathrm{a}} \pm 0.019\end{array}$ & $\begin{array}{l}-0.329^{\mathrm{a}} \pm 0.025^{* * *} \\
-0.056^{\mathrm{a}} \pm 0.031 \\
-0.029^{\mathrm{a}} \pm 0.021\end{array}$ & $\begin{array}{l}-0.561^{\mathrm{b}} \pm 0.022^{* * *} \\
-0.227^{\mathrm{b}} \pm 0.037^{* * *} \\
-0.104^{\mathrm{b}} \pm 0.023^{* *}\end{array}$ \\
\hline \multicolumn{7}{|c|}{$\begin{array}{l}\text { Vascular plant species } \\
\text { richness }\end{array}$} \\
\hline $\begin{array}{l}2000 \\
2004 \\
2012\end{array}$ & $\begin{array}{l}0.4(0.677) \\
1.3(0.300) \\
1.7(0.208)\end{array}$ & $\begin{array}{c}10.7(<0.001) \\
18.3(<0.001) \\
6.1(0.004)\end{array}$ & $\begin{array}{l}1.2(0.383) \\
1.5(0.228) \\
2.4(0.061)\end{array}$ & $\begin{array}{l}-0.501^{\mathrm{a}} \pm 0.032 \\
-0.015^{\mathrm{a}} \pm 0.033 \\
-0.031^{\mathrm{a}} \pm 0.028\end{array}$ & $\begin{array}{l}-0.117^{\mathrm{a}} \pm 0.031^{* *} \\
-0.050^{\mathrm{a}} \pm 0.028 \\
-0.054^{\mathrm{a}} \pm 0.033\end{array}$ & $\begin{array}{l}-0.209^{\mathrm{b}} \pm 0.029^{* * *} \\
-0.187^{\mathrm{b}} \pm 0.028^{* * *} \\
-0.135^{\mathrm{b}} \pm 0.037^{*}\end{array}$ \\
\hline \multicolumn{7}{|l|}{$\begin{array}{l}\text { Scores for vascular } \\
\text { plant PC1 }\end{array}$} \\
\hline $\begin{array}{l}2000 \\
2004 \\
2012\end{array}$ & $\begin{array}{l}0.0(0.980) \\
0.4(0.685) \\
0.0(0.972)\end{array}$ & $\begin{array}{l}8.8(<0.001) \\
6.8(0.002) \\
0.1(0.898)\end{array}$ & $\begin{array}{l}0.3(0.893) \\
0.1(0.977) \\
0.6(0.672)\end{array}$ & $\begin{array}{r}-0.076^{\mathrm{a}} \pm 0.225 \\
-0.205^{\mathrm{a}, \mathrm{b}} \pm 0.207 \\
-0.260 \pm 0.268\end{array}$ & $\begin{array}{r}-0.438^{\mathrm{a}} \pm 0.207 \\
0.218^{\mathrm{a}} \pm 0.188 \\
-0.204 \pm 0.284\end{array}$ & $\begin{array}{c}-0.925^{\mathrm{b}} \pm 0.235^{* * *} \\
-0.534^{\mathrm{b}} \pm 0.218^{*} \\
-0.297 \pm 0.248\end{array}$ \\
\hline \multicolumn{7}{|l|}{$\begin{array}{l}\text { Vaccinium myrtillus } \\
\text { cover }\end{array}$} \\
\hline $\begin{array}{l}2000 \\
2004 \\
2012\end{array}$ & $\begin{array}{l}0.2(0.828) \\
1.1(0.365) \\
0.4(0.699)\end{array}$ & $\begin{array}{l}1.2(0.315) \\
1.3(0.276) \\
0.1(0.907)\end{array}$ & $\begin{array}{l}1.2(0.337) \\
0.5(0.713) \\
1.1(0.379)\end{array}$ & $\begin{array}{r}-0.137 \pm 0.091 \\
0.067 \pm 0.087 \\
0.054 \pm 0.096\end{array}$ & $\begin{array}{r}-0.198 \pm 0.084 \\
0.002 \pm 0.083 \\
0.044 \pm 0.097\end{array}$ & $\begin{array}{r}-0.260 \pm 0.073 \\
-0.041 \pm 0.086 \\
0.025 \pm 0.085\end{array}$ \\
\hline \multicolumn{7}{|c|}{$\begin{array}{l}\text { Vaccinium vitis-idaea } \\
\text { cover }\end{array}$} \\
\hline $\begin{array}{l}2000 \\
2004 \\
2012\end{array}$ & $\begin{array}{l}0.9(0.434) \\
0.1(0.889) \\
0.8(0.477)\end{array}$ & $\begin{array}{c}42.6(<0.001) \\
14.5(<0.001) \\
0.3(0.720)\end{array}$ & $\begin{array}{l}0.8(0.513) \\
0.6(0.658) \\
0.3(0.905)\end{array}$ & $\begin{array}{c}-0.293^{\mathrm{a}} \pm 0.040^{* * *} \\
0.230^{\mathrm{a}} \pm 0.054 \\
-0.097 \pm 0.062\end{array}$ & $\begin{aligned}-0.336^{\mathrm{a}} & \pm 0.036^{* * *} \\
-0.048^{\mathrm{a}} & \pm 0.050 \\
-0.039 & \pm 0.024\end{aligned}$ & $\begin{array}{c}-0.658^{\mathrm{b}} \pm 0.034^{* * *} \\
-0.281^{\mathrm{b}} \pm 0.072^{* * *} \\
-0.143 \pm 0.065^{*}\end{array}$ \\
\hline \multicolumn{7}{|l|}{$\begin{array}{l}\text { Empetrum } \\
\text { hermaphroditum } \\
\text { cover }\end{array}$} \\
\hline $\begin{array}{l}2000 \\
2004 \\
2012\end{array}$ & $\begin{array}{l}1.2(0.323) \\
1.3(0.304) \\
1.3(0.300)\end{array}$ & $\begin{array}{r}8.0(<0.001) \\
21.7(<0.001) \\
12.0(<0.001)\end{array}$ & $\begin{array}{l}1.0(0.399) \\
1.1(0.360) \\
1.4(0.247)\end{array}$ & $\begin{array}{l}-0.696^{\mathrm{a}} \pm 0.067^{* * *} \\
-0.419^{\mathrm{a}} \pm 0.024^{* * *} \\
-0.279^{\mathrm{a}} \pm 0.098\end{array}$ & $\begin{aligned} &-0.758^{\mathrm{a}, \mathrm{b}} \pm 0.069^{* * *} \pm 0 \\
&-0.474^{\mathrm{a}} \pm 0.092^{* * *} \pm 0.155^{\mathrm{a}} \pm 0.102 \\
&-0.0\end{aligned}$ & $\begin{array}{l}-0.833^{\mathrm{b}} \pm 0.069^{* * * *} \\
-0.892^{\mathrm{b}} \pm 0.055^{* * *} \\
-0.692^{\mathrm{b}} \pm 0.081^{* * *}\end{array}$ \\
\hline \multicolumn{7}{|l|}{ Total moss biomass } \\
\hline 2012 & $1.6(0.236)$ & $14.4(<0.001)$ & $0.8(0.513)$ & $-0.285^{\mathrm{a}} \pm 0.108^{*}$ & $-0.645^{\mathrm{b}} \pm 0.063^{* * *}$ & $-0.786^{\mathrm{b}} \pm 0.069^{* * *}$ \\
\hline \multicolumn{7}{|c|}{$\begin{array}{l}\text { Hylocomium splendens } \\
\text { biomass }\end{array}$} \\
\hline 2012 & $1.0(0.387)$ & $3.9(0.025)$ & $0.7(0.566)$ & $-0.436^{\mathrm{a}} \pm 0.121^{* *}$ & $-0.590^{\mathrm{a}, \mathrm{b}} \pm 0.108^{* * *}$ & $-0.880^{\mathrm{b}} \pm 0.072^{* * *}$ \\
\hline \multicolumn{7}{|l|}{$\begin{array}{l}\text { Pleurozium schreberi } \\
\text { biomass }\end{array}$} \\
\hline 2012 & $2.8(0.084)$ & $5.8(0.005)$ & $1.5(0.265)$ & $-0.284^{\mathrm{a}} \pm 0.134^{*}$ & $-0.598^{\mathrm{a}} \pm 0.092^{* * *}$ & $-0.660^{\mathrm{b}} \pm 0.109^{* * *}$ \\
\hline
\end{tabular}

Notes: PC1 stands for first principal component, as derived from ordination analysis. For all variables except PC1, values are for index $V$, which provides a measure for the response to disturbance and ranges from -1 to +1 ; it is negative or positive depending on whether the value in the disturbed plot is less or greater than the value in the corresponding control plot (see Methods). For PC1, each value is the ordination score of the disturbed plot minus that of the control plot. ANOVA results are $F$ ratios, with $P$ values in parentheses. Degrees of freedom are 2, 18 for $I ; 2,54$ for $D$; and 4, 54 for $I \times D$. $F$ and $P$ values are statistically significant at $P=$ 0.05 . Numbers in the same row followed by the same letter do not differ at $P=0.05$ (Tukey's test). Significant differences between disturbed treatment and undisturbed control are indicated by asterisks.

$* P=0.05 ; * * P=0.01 ; * * * P=0.001$.

least time to recover on large islands, especially for the trimming treatments (Fig. 2). The recovery of $E$. hermaphroditum to all disturbance treatments was slow for all size classes, and was negligible in the burned treatment, even after $14 \mathrm{yr}$ (Fig. 2). The index $V$ revealed that neither island size nor its interactive effect with disturbance influenced the resilience of any species measured in any year. However, for V. vitis-idaea and
E. hermaphroditum, resilience did vary among disturbance treatments through being least in the burned treatment, and having not fully recovered in that treatment even after $14 \mathrm{yr}$ (Table 1).

Fourteen years after treatments were imposed, biomass of each of the two moss species (P. schreberi and $H$. splendens) and total moss biomass were all unresponsive to the interactive effects of island size with 

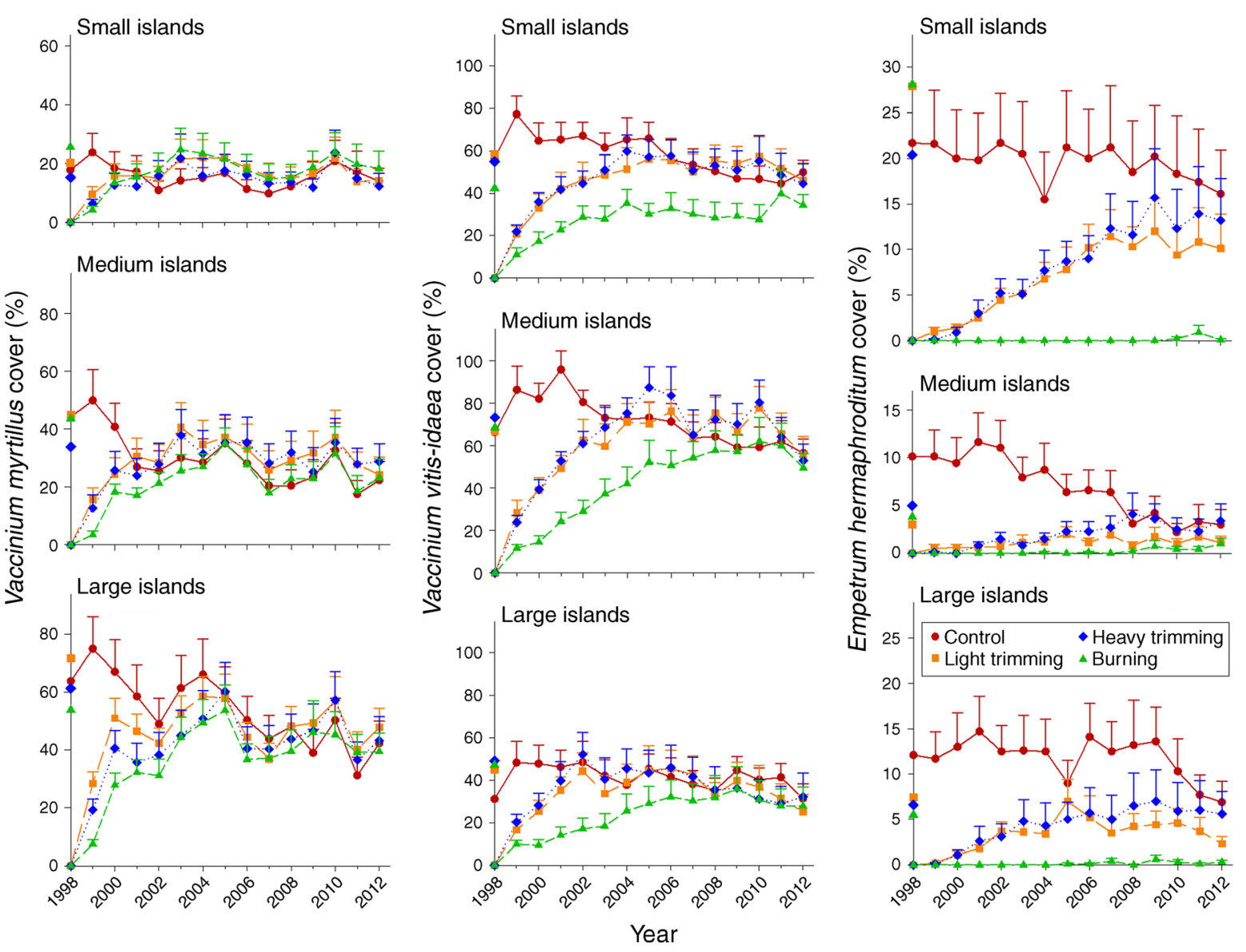

FIG. 2. Total cover (i.e., numbers of total vegetation intercepts by 100 points) for Vaccinium myrtillus, Vaccinium vitis idaea, and Empetrum hermaphroditum in plots differing in a single disturbance applied in 1998, on small, medium, and large islands over a 14-yr period. Red circles indicate no disturbance (control); orange squares indicate disturbance by light trimming; blue diamonds indicate disturbance by heavy trimming; and green triangles indicate disturbance by burning. Symbols placed directly on the $y$-axis represent cover immediately before the disturbance was initiated, after which cover for the light trimming, heavy trimming, and burning treatments was zero. The vertical scale spacing is constant within species but differs between species. Vertical bars represent standard errors. ANOVA results are shown in Appendix 3.

disturbance (in contradiction to the predictions of the first hypothesis), but did differ among disturbance treatments (Appendix B). As such, biomass of both species was significantly less in all disturbance treatments than in the control, with the lowest biomass in the burned treatment (Table 2). This was confirmed by the index $V$ (Table 1), which showed that mosses had not fully recovered by year 14 in any disturbance treatment, and with the burned treatment showing the lowest resilience. Values of index $V$, and therefore resilience for the mosses, were unaffected by island size (Table 1).

\section{Belowground measurements}

For all soil abiotic properties, effects of disturbance were always independent of effects of island size, as there was no interactive effect among these two factors (Appendix C); this is inconsistent with the predictions of the second hypothesis. Furthermore, while island size

TABLE 2. Biomass of mosses (mean \pm SE) in response to disturbance treatments in 2012, 14 yr after disturbance treatments were applied.

\begin{tabular}{lrcrr}
\hline \hline \multirow{2}{*}{\multicolumn{1}{c}{ Response variable }} & \multicolumn{3}{c}{ Disturbance treatment } \\
\cline { 2 - 5 } \multicolumn{1}{c}{ Control } & Light trimming & Heavy trimming & Burning \\
\hline Total moss biomass $\left(\mathrm{g} / \mathrm{m}^{2}\right)$ & $228.4^{\mathrm{a}} \pm 34.5$ & $133.7^{\mathrm{b}} \pm 26.7$ & $63.0^{\mathrm{b}, \mathrm{c}} \pm 13.1$ & $20.0^{\mathrm{c}} \pm 5.1$ \\
Hylocomium splendens biomass $\left(\mathrm{g} / \mathrm{m}^{2}\right)$ & $71.2^{\mathrm{a}} \pm 18.2$ & $40.1^{\mathrm{a}, \mathrm{b}} \pm 12.1$ & $23.9^{\mathrm{b}} \pm 8.1$ & $4.7^{\mathrm{b}} \pm 1.7$ \\
Pleurozium schreberi biomass $\left(\mathrm{g} / \mathrm{m}^{2}\right)$ & $157.1^{\mathrm{a}} \pm 33.9$ & $93.6^{\mathrm{a}, \mathrm{b}} \pm 25.1$ & $39.1^{\mathrm{b}, \mathrm{c}} \pm 9.8$ & $15.3^{\mathrm{c}} \pm 4.7$ \\
\hline
\end{tabular}

Notes: Within each row, numbers followed by the same letter are not significantly different at $P=0.05$ (Tukey's test following ANOVA). ANOVA results are shown in Appendix A. 

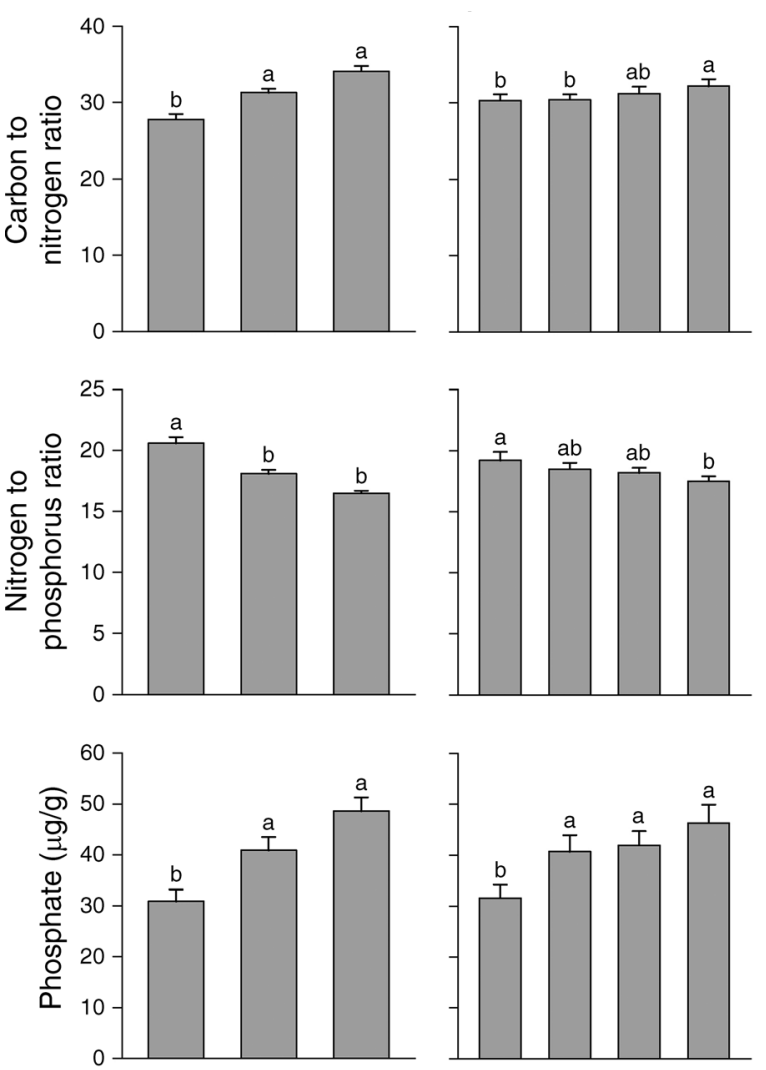

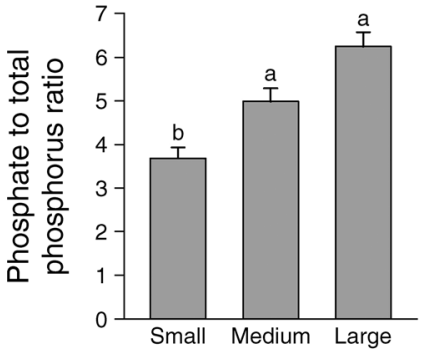

Island size

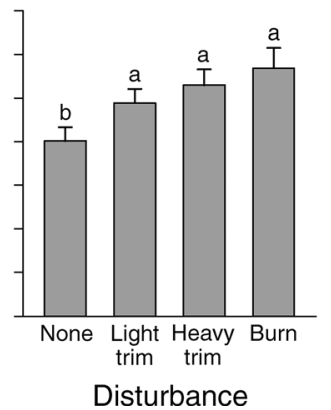

Disturbance
FIG. 3. Selected soil nutrient variables in response to island size and disturbance treatments in 2012, $14 \mathrm{yr}$ after disturbance treatments were applied. Within each panel, bars topped with the same letter are not significantly different at $P=0.05$ (Tukey's test following ANOVA). Vertical bars represent standard errors. ANOVA results are shown in Appendix D.

influenced soil abiotic properties positively (i.e., $\mathrm{pH}$, total $\mathrm{C}, \mathrm{C}$ to $\mathrm{N}$ ratio, mineral $\mathrm{N}$, phosphate, and the ratios of mineral to total $\mathrm{N}$ and mineral to total $\mathrm{P}$ ) or negatively (i.e., total $\mathrm{N}, \mathrm{N}$ to $\mathrm{P}$ ratio), after $14 \mathrm{yr}$, the disturbance treatments had significant effects on only four properties, i.e., $\mathrm{C}$ to $\mathrm{N}$ ratio, $\mathrm{N}$ to $\mathrm{P}$ ratio, phosphate, and the ratio of mineral to total $\mathrm{P}$ (Appendix C, Fig. 3). Of these four variables, values were least in the burned treatment for the $\mathrm{N}$ to $\mathrm{P}$ ratio and greatest in that treatment for the other three (Fig. 3). Further, measures of the index $V$ revealed no effect of island size or its interactive effect with disturbance on the resilience of any soil abiotic variable (Table 3), inconsistent with the second hypothesis. However, values of $V$ for soil $\mathrm{C}$ to $\mathrm{N}$ and $\mathrm{N}$ to $\mathrm{P}$ ratios varied significantly among disturbance treatments, through being most different from 0 in the burned treatment. For both these variables, and for phosphate and the mineral to total $\mathrm{P}$ ratio, values of $V$ differed significantly from 0 after 14 $\mathrm{yr}$ in the burned treatment. Further, values differed significantly from 0 for phosphate in both trimmed treatments, and for the mineral to total $\mathrm{P}$ ratio in the heavy trimming treatment (Table 3 ).

There were no interactive effects between island size and disturbance on any soil biotic variable (Appendix D), meaning that the second hypothesis was unsupported. Only two soil biotic properties varied with island size, SIR and the decomposition rate of surface placed litter bags (Appendix D); both were greater on large islands (data not presented). These variables were unaffected by disturbance treatment. However, disturbance significantly influenced all variables derived from the PLFA measurements, except for cyclic PLFAs and PC2 scores for the PLFA data (Appendix D). As such, fungal PLFAs were greatest in the burned treatment, while bacterial, branched, and actinomycete PLFAs, and the bacterial to fungal PLFA ratio, were lowest in that treatment (Fig. 4). Furthermore, PC1 scores for the PLFAs differed significantly between the burned treatment and the other three (Fig. 4). Measures of the index $V$ showed that the resilience for all soil biotic properties was unaffected by island size and its interaction with disturbance treatment, but did differ significantly among disturbance treatments for five variables and almost significantly for a sixth (Table 3). As such, for each of the PLFA variables, resilience was least in the burned treatment, and after $14 \mathrm{yr}$ had still not fully recovered in that treatment (Table 3).

\section{DisCUSSION}

\section{Aboveground variables}

Several short-term experiments provide evidence that plant communities can vary considerably in their initial response to disturbances, as a consequence of differences in both abiotic and biotic properties (e.g., McGillivray et al. 1995, Sankaran and McNaughton 1999, Gendron and Wilson 2007). In comparison, our results showed that for a long-term experiment involving disturbances of varying intensity on contrasting islands (Appendix A), recovery of plant community properties varied, but not greatly, across ecosystems that differed in soil fertility and productivity. All community-level variables recovered from the most severe disturbance (burning) more slowly on smaller than on larger, more fertile islands, but not substantially so (Fig. 1), which provided only weak support for our first hypothesis. Further, community recovery from the other disturbance (i.e., trimming) treatments was not significantly affected by island size. We also found that the significantly slower 
TABLE 3. Impact of disturbance applied in 1998 on selected belowground properties in 2012 (year 14).

\begin{tabular}{|c|c|c|c|c|c|c|}
\hline \multirow[b]{2}{*}{ Response variable } & \multicolumn{3}{|c|}{ ANOVA results } & \multicolumn{3}{|c|}{ Response to disturbance (mean $\pm \mathrm{SE}$ ) } \\
\hline & $\begin{array}{l}\text { Island } \\
\text { size }(I)\end{array}$ & $\begin{array}{l}\text { Disturbance } \\
\text { treatment }(D)\end{array}$ & $I \times D$ & Light trimming & Heavy trimming & Burning \\
\hline oil $\mathrm{C}$ to & 297) & 3.2 & 6) & $0.004^{\mathrm{b}} \pm 0.009$ & $0.016^{\mathrm{a}, \mathrm{b}} \pm 0.012$ & $0.029^{\mathrm{a}}$ \\
\hline oil $\mathrm{N}$ tc & & & & $-0.013^{\mathrm{a}} \pm 0.013$ & $-0.021^{\mathrm{a}} \pm 0.015$ & $-0.042^{\mathrm{b}}$ \\
\hline Phosphate co & $3(0.084)$ & 1.4( & & $0.044 \pm 0.017^{*}$ & $0.052 \pm 0.016^{*}$ & $0.062 \pm 0.014 * * *$ \\
\hline Mineral $\mathrm{P}$ to total $\mathrm{P}$ ratio $\dagger$ & $2.9(0.071)$ & 2.1( & 0.5( & $0.125 \pm 0.052$ & $0.150 \pm 0.059^{*}$ & $0.182 \pm 0.079 *$ \\
\hline PLFAs' & $1.7(0.197)$ & $003)$ & $0.7(0.590)$ & $0.003^{\mathrm{a}} \pm 0.019$ & $-0.014^{\mathrm{a}} \pm 0.025$ & $-0.167^{\mathrm{b}} \pm 0.078^{*}$ \\
\hline Fun & 023 & 2.9 & & $0.060^{\mathrm{a}, \mathrm{b}} \pm 0.031$ & $0.020^{\mathrm{b}} \pm 0.035$ & $0.095^{\mathrm{a}} \pm 0.035^{*}$ \\
\hline FAs & $1.8(0.198)$ & $003)$ & 2) & $-0.010^{\mathrm{a}} \pm 0.021$ & $-0.022^{\mathrm{a}} \pm 0.025$ & $-0.078^{\mathrm{b}} \pm 0.028^{*}$ \\
\hline te PLFAs & $2.0(0.169)$ & $3.2(0.049)$ & $1.6(0.210)$ & $-0.022^{\mathrm{a}, \mathrm{b}} \pm 0.018$ & $-0.016^{\mathrm{a}} \pm 0.020$ & $-0.066^{\mathrm{b}} \pm 0.025^{*}$ \\
\hline $\begin{array}{l}\text { Bacterial to fungal PLFA } \\
\text { ratio }\end{array}$ & $0.5(0.609)$ & $15.4(<0.001)$ & $1.4(0.235)$ & $-0.017^{\mathrm{a}} \pm 0.011$ & $-0.012^{\mathrm{a}} \pm 0.011$ & $-0.058^{\mathrm{b}} \pm 0.011^{* * *}$ \\
\hline Scores for PC1 of PLFAs $\dagger$ & $3(0.721)$ & $9.6(<0.001)$ & 3) & $0.930^{\mathrm{b}} \pm 0.536$ & $0.570^{\mathrm{b}} \pm$ & $2.342^{\mathrm{a}} \pm$ \\
\hline
\end{tabular}

Notes: PFLA stands for phospholipid fatty acid; PCl stands for first principal component. ANOVA results are $F$ ratios, with $P$ values in parentheses. Degrees of freedom are 2, 18 for $I ; 2,54$ for $D$, and 4, 54 for $I \times D$. $F$ and $P$ values are statistically significant at $P=0.05$. Numbers in the same row followed by the same letter do not differ at $P=0.05$ (Tukey's test). For all variables except $\mathrm{PC} 1$, values are for index $V$, which provides a measure for the response to disturbance and ranges from -1 to +1 ; it is negative or positive depending on whether the value in the disturbed plot is less or greater than the value in the corresponding control plot (see Methods). For PC1, each value is the ordination score of the disturbed plot minus that of the control plot. Significant differences between disturbed treatment and undisturbed control are indicated by asterisks.

$\dagger$ Values of $V$ calculated using log-transformed data.

* $P=0.05 ; * * P=0.01 ; * * * P=0.001$.

recovery of the burning treatment on the small islands was insufficient to influence resilience index measures (Appendix A). This is possibly in part because these measures involved a less powerful analysis (each index is based on a ratio of two variables that each contains variance), but nevertheless highlights the fact that differences among island size classes in recovery to even severe disturbance was not large. Our results also highlight the need for long-term experiments to understand recovery patterns of communities and ecosystems to disturbance; our data on the recovery of the vegetation in the first two or so years post-disturbance (i.e.,. comparable to the duration of most previous studies) provided an incomplete picture either of recovery over a decadal timeframe, or how this recovery may have varied among contrasting ecosystems. However, even with our study, we caution that our response variables had not fully recovered from our most severe perturbations (i.e., burning) after $14 \mathrm{yr}$, and that studies of longer duration are necessary to more fully understand how the understory vegetation in ecosystems recover from intense disturbances, such as fire, in our system.

These plant community results have two further implications, relating to understanding the response and role of plant community diversity. First, while our study involved disturbance treatments varying greatly in severity, there was no evidence of any disturbance having promoted plant diversity relative to the control. This contrasts with classical theories predicting that intermediate disturbance promotes diversity (Grime 1973, Connell 1978), but is consistent with much empirical data (Mackey and Currie 2001, Hughes et al. 2007), and suggests that reduced competition from loss of dominants did not lead to a more diverse community.
It is, however, possible that the small size of the species pool in our study system limited the potential for responses of community diversity to disturbance, which may have worked against intermediate disturbances promoting diversity. Second, we did not find greater resilience on smaller, more floristically diverse islands. While at the $0.25-\mathrm{m}^{2}$ plot scale used in this study species richness was significantly but not substantially greater on the small islands, at larger scales (i.e., the $314-\mathrm{m}^{2}$ plot scale) species richness was considerably greater on the small islands (Appendix A). Despite many studies suggesting that greater diversity has stabilizing effects (Cardinale et al. 2012), our results show that the effects of the greater vegetation diversity on the small islands were of insufficient strength to be detectable against the background of other driving factors.

We found that of the three dominant vascular plant species in our study (comprising 95\% of vascular plant biomass), E. hermaphroditum, which is most abundant on small islands, showed the slowest recovery to disturbance, while $V$. myrtillus, which dominates on large islands, showed the fastest recovery, both independently of island size. These three species vary in their functional traits (Appendix E), with V. myrtillus having traits more associated with resource acquisition (versus conservation) relative to the other two. Significantly, $E$. hermaphroditum is less productive than the other species and shows a lower rate of biomass turnover (Wardle and Zackrisson 2005; Appendix E), in part because it allocates a substantial amount of its fixed $\mathrm{C}$ into secondary compounds rather than new biomass (Nilsson and Wardle 2005). It also has a poor capacity to reestablish by seeds once it has been lost from the plant community (Baskin et al. 2002). Consistent with these attributes, we found the recovery of E. hermaphroditum 

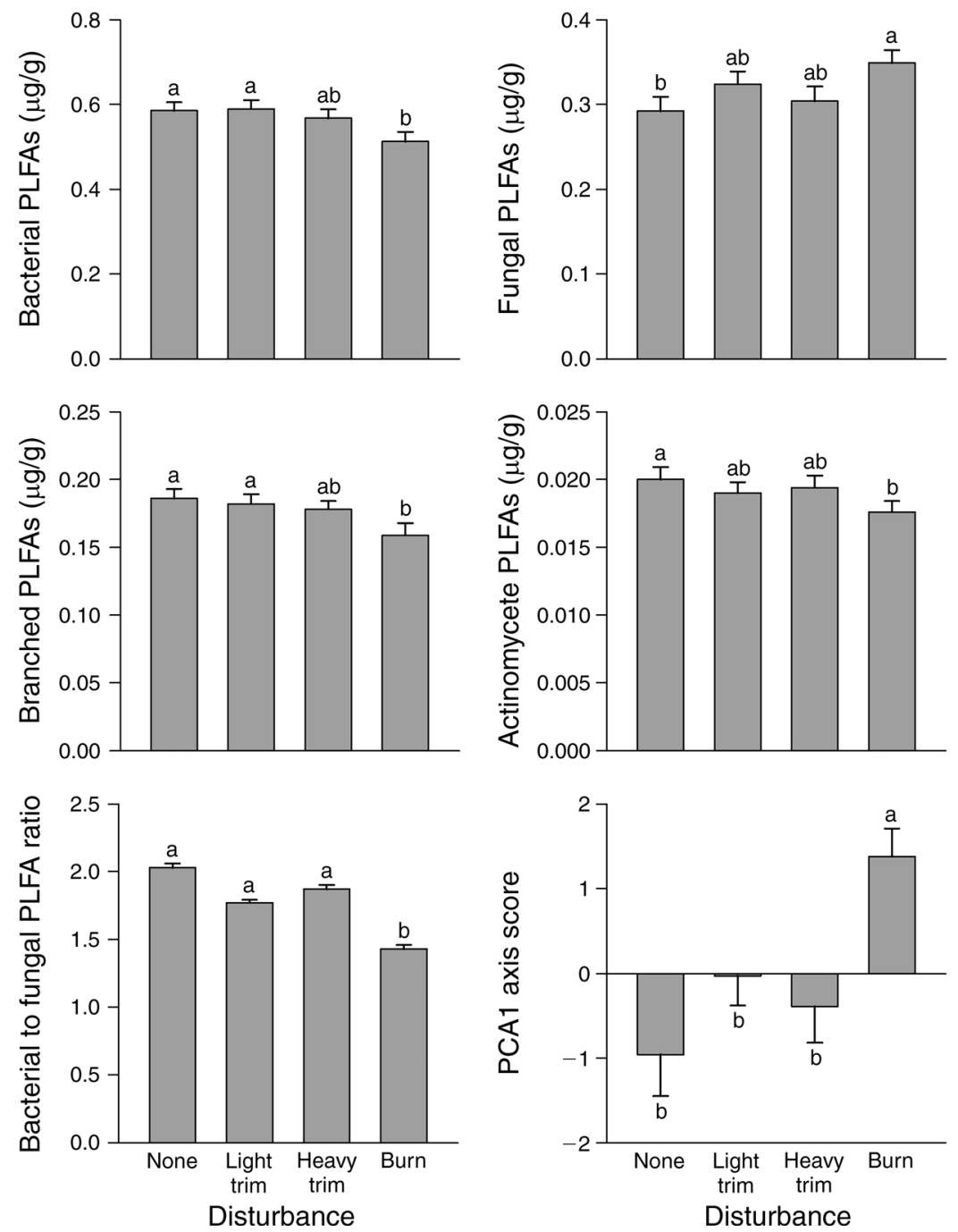

FIG. 4. Microbial PLFA (phospholipid fatty acid) variables in response to disturbance treatments in $2012,14 \mathrm{yr}$ after disturbance treatments were applied. Within each panel, bars topped with the same letter are not significantly different at $P=0.05$ (Tukey's test following ANOVA). Vertical bars are standard errors. ANOVA results are shown in Appendix E.

on the burned plots to be negligible even $14 \mathrm{yr}$ after disturbance, long after the other species had mostly or fully recovered. As E. hermaphroditum is a major component of total biomass only on small islands, the slower recovery of total cover following burning on those islands would appear to have been due largely to the virtual absence of this species from the plots, and the inability of the remaining species to have fully compensated for its lost biomass. Furthermore, the lower recovery of species richness on burned plots for small islands was largely because E. hermaphroditum failed to establish on the majority of these plots, which effectively reduced species richness in these plots by one. In any case, our results highlight that functional composition of vegetation serves as a major determinant of communitylevel responses to disturbance, not only initially (McGillivray et al. 1995, Sankaran and McNaughton
1999, Bernhardt-Römermann et al. 2011), but also for several years after the disturbance.

Feather mosses showed particularly poor recovery from disturbance even after $14 \mathrm{yr}$; they not only recovered little in the burned treatment, but were the only plants to have not fully or mostly recovered in the trimming treatments. Significantly, moss biomass was substantially less in the lightly trimmed plots than in the control plots after $14 \mathrm{yr}$, despite this treatment having involved only the trimming of shrubs. This adverse affect of trimming the shrubs may have emerged because dwarf shrubs benefit mosses by protecting them and holding them in position during disturbance, as previously shown through shrub removal experiments along this island gradient (Gundale et al. 2010). We did not find the effects of disturbance on mosses, or their resilience, to vary with island size, meaning that the long-term legacy effects of disturbances on feather 
mosses remained invariant across ecosystems that differ in soil fertility, productivity, and functional composition of the plant community. Given the multiple ecosystem roles that feather mosses perform, including supporting $\mathrm{N}_{2}$-fixing cyanobacteria, slowing nutrient cycling and decomposition, and buffering soil microclimate (Lindo and Gonzalez 2010, Turetsky et al. 2012), their low resilience to even mild disturbances is likely to impact on ecological processes over the long term in any boreal forest in which they are otherwise abundant.

\section{Belowground variables}

We found that all belowground properties had fully recovered after $14 \mathrm{yr}$ in the trimmed, but not in the burned treatments. However, for properties that had not recovered, there was no difference among island size classes either in the extent to which the legacy of burning had influenced them, or in their resilience index values, leaving our second hypothesis unsupported. This means that although we found a slower recovery of the plant community to burning on small islands, this was not paralleled by an impaired recovery of the belowground subsystem relative to the large islands, at least by year 14. This highlights that, in contrast to our predictions, any differences in vegetation recovery among island size classes were insufficient to have altered belowground properties. It also indicates some decoupling between the aboveground and belowground subsystems in the manner sometimes observed in other ecosystems in this region supporting similar ground layer vegetation (Wardle et al. 2013).

There were 14-yr-old legacy effects of burning on several abiotic soil variables indicative of increased $\mathrm{P}$ relative to $\mathrm{N}$ availability (i.e., enhanced $\mathrm{C}$ to $\mathrm{N}$ and reduced $\mathrm{N}$ to $\mathrm{P}$ ratios, and enhanced phosphate concentration). These could have arisen from less uptake of $\mathrm{P}$ due to less plant biomass (causing phosphate to accumulate in the soil), reduced $\mathrm{N}$ inputs from fixation by cyanobacteria associated with the loss of mosses (De Luca et al. 2002), or conversion of $P$ to more available forms by the burning itself (Lagerström et al. 2009). With regard to soil microbial variables, after $14 \mathrm{yr}$, burning had a negative legacy effect on bacterial groups and a positive effect on fungi. This runs counter to those studies that have pointed to greater bacterial to fungal ratios following disturbance (Wardle 2002), but is consistent with bacteria being promoted by superior soil moisture conditions frequently associated with greater moss biomass (Jackson et al. 2013), and with moss biomass having been greatly impaired in the burned treatment. In any case, the fact that all belowground legacy effects were invariant across island size classes suggests that even large differences among contrasting ecosystems in soil fertility, productivity, and vegetation composition were insufficient to alter the extent to which soil chemical and biotic properties had recovered $14 \mathrm{yr}$ after disturbance.

\section{CONCLuSions}

Although several studies have explored how contrasting communities and ecosystems respond to disturbance in the short term, our knowledge of how they recover over the longer time scales required to assess resilience remains limited. Our results reveal that even $14 \mathrm{yr}$ after disturbances were applied to island ecosystems varying greatly in size (and therefore soil fertility and ecosystem productivity), the recovery of community and ecosystem properties showed only a modest response to island size aboveground, and no detectable response belowground. These results have several implications. First, they show that differences in resilience among ecosystems are most likely driven by differences in the functional characteristics of the vegetation. In this study, E. hermaphroditum and the feather mosses recovered much more slowly from disturbance than did the other plant species present, and the fact that abundance of $E$. hermaphroditum varied with island size was sufficient to explain any variation in the resilience of whole-community properties observed among islands. Second, the lack of any detectable effect of island size on the recovery of any belowground property at least $14 \mathrm{yr}$ after the disturbance means that any belowground consequences of island size effects on vegetation recovery were either transient or nonexistent, indicative of a possible decoupling of aboveground and belowground responses to environmental perturbation (Wardle et al. 2013). Furthermore, while several studies have shown large variation among plant communities in their short-term resistance to environmental perturbations (e.g., Sankaran and McNaughton 1999, BernhardtRömermann et al. 2011), our results reveal that when perturbations are applied equally to highly contrasting ecosystems, differences in resilience among them in the longer term can be relatively minor. Although comparable long-term experimental studies from elsewhere are largely lacking, our results highlight that contrasting ecosystems can show reasonably similar patterns of recovery following perturbation, irrespective of the severity of disturbance imposed.

\section{ACKNOWLEDGMENTS}

We thank Peter Bellingham, Kristin Svavarssdottir, and Morgan Karlsson with help in setting up the disturbance plots, Kelley Gundale for preparing the figures, and Jordan Mayor and two anonymous reviewers for helpful comments on an earlier draft. This work was supported by grants from Vetenskaprådet and a Wallenberg Scholars award to D. A. Wardle, and from Vetenskaprådet and FORMAS to M. Jonsson.

\section{Literature Cited}

Anderson, J. P. E., and K. H. Domsch. 1978. A physiologically active method for the quantification of microbial biomass in soil. Soil Biology and Biochemistry 10:215-221.

Baskin, C. C., O. Zackrisson, and J. M. Baskin. 2002. Role of warm stratification in promoting germination of seeds of Empetrum hermaphroditum (Empetraceae), a circumboreal species with a stony endocarp. American Journal of Botany 89:486-493. 
Batista, W. B., and W. J. Platt. 2003. Tree population responses to hurricane disturbance: syndromes in a south-eastern USA old-growth forest. Journal of Ecology 91:197-212.

Bernhardt-Römermann, M., et al. 2011. Functional traits and local environment predict vegetation responses to disturbance: a pan-European multi-site experiment. Journal of Ecology 99:77-87.

Bligh, E. G., and W. G. Dyer. 1959. A rapid method of total lipid extraction and purification. Canadian Journal of Biochemistry and Physiology 37:911-917.

Bokhorst, S., J. W. Bjerke, H. Tømmervik, T. V. Callaghan, and G. K. Phoenix. 2009. Winter warming events damage sub-Arctic vegetation: consistent evidence from an experimental manipulation and a natural event. Journal of Ecology 97:1408-1415.

Cardinale, B. J., et al. 2012. Biodiversity loss and its impact on humanity. Nature 486:59-67.

Chillo, V., M. Anand, and R. A. Ojeda. 2011. Assessing the use of functional diversity as a measure of ecological resilience in arid rangelands. Ecosystems 14:1168-1177.

Connell, J. 1978. Diversity in tropical rain forests and coral reefs. Science 199:1302-1310

De Luca, T. H., O. Zackrisson, M.-C. Nilsson, and A. Sellstedt. 2002. Quantifying nitrogen-fixation in feather moss carpets of boreal forests. Nature 419:917-920.

Freschet, G. T., W. K. Cornwell, D. A. Wardle, T. G. Elumeeva, W. Liu, B. G. Jackson, V. G. Onipchenko, N. A. Soudzilovskaia, J. Tao, and J. H. C. Cornelissen. 2013 Linking litter decomposition of above and belowground organs to plant-soil feedbacks worldwide. Journal of Ecology 101:943-954.

Frostegård, A., and E. Bååth. 1996. The use of phospholipid analysis to estimate bacterial and fungal biomass in soil. Biology and Fertility of Soils 22:59-65.

Gendron, F., and S. D. Wilson. 2007. Responses to soil fertility and disturbance in a low diversity grassland. Plant Ecology 191:199-207.

Grime, J. P. 1973. Competitive exclusion in herbaceous vegetation. Nature 242:344-347.

Grimm, V., and C. Wissel. 1997. Babel, or the ecological stability discussions: an inventory and analysis of terminology and a guide for avoiding confusion. Oecologia 109:323334.

Gundale, M. J., D. A. Wardle, and M. C. Nilsson. 2010. Vascular plant removal effects on biological $\mathrm{N}$ fixation vary across a boreal forest island gradient. Ecology 91:1704-1714.

Holling, C. S. 1973. Resilience and stability of ecological systems. Annual Review of Ecology and Systematics 4:1-23.

Hooper, D. U., et al. 2005. Effects of biodiversity on ecosystem functioning: a consensus of current knowledge and needs for future research. Ecological Monographs 75:3-35.

Hughes, A. R., J. E. Byrnes, D. L. Kimbro, and J. J. Stachowicz. 2007. Reciprocal relationships and potential feedbacks between diversity and disturbance. Ecology Letters 10:849-864.

Ives, A. R., and S. R. Carpenter. 2007. Stability and diversity of ecosystems. Science 317:58-62.

Jackson, B. G., M. C. Nilsson, and D. A. Wardle. 2013. The effects of the moss layer on the decomposition of intercepted vascular plant litter across a post-fire boreal forest chronosequence. Plant and Soil 367:199-214.

Kroppenstedt, R. M. 1985. Fatty acid menaquinone analysis of actinomycetes and related organisms. Pages 173-199 in M. Goodfellow and D. E. Minnikin, editors. Chemical methods in bacterial systematics. Academic Press, New York, New York, USA

Lagerström, A., C. Esberg, D. A. Wardle, and R. Giesler. 2009 Soil phosphorus and microbial response to a long-term wildfire chronosequence in northern Sweden. Biogeochemistry 95:199-213.

Lagerström, A., M. C. Nilsson, and D. A. Wardle. 2013 Decoupled responses of tree and shrub leaf and litter trait values to ecosystem retrogression across an island area gradient. Plant and Soil 367:183-197.
Lagerström, A., M. C. Nilsson, O. Zackrisson, and D. A. Wardle. 2007. Ecosystem input of nitrogen through biological fixation in feather mosses during ecosystem retrogression. Functional Ecology 21:1027-1033.

Lindo, Z., and A. Gonzalez. 2010. The bryosphere: an integral and influential component of the earth's biosphere. Ecosystems 13:612-627.

Mackey, R. L., and D. J. Currie. 2001. The diversitydisturbance relationship: is it generally strong and peaked? Ecology 82:3479-3492.

McGillivray, C. W., et al. 1995. Testing predictions of the resistance and resilience of vegetation subjected to extreme events. Functional Ecology 9:640-649.

Mouillot, D., N. A. J. Graham, S. Villeger, N. H. W. Mason, and D. R. Bellwood. 2013. A functional approach reveals community responses to disturbance. Trends in Ecology and Evolution 28:167-177.

Nilsson, M. C., and D. A. Wardle. 2005. Understory vegetation as a forest ecosystem driver: evidence from the northern Swedish boreal forest. Frontiers in Ecology and the Environment 3:421-428.

Norberg, G., A. Jäderlund, O. Zackrisson, T. Nordfjell, D. A. Wardle, M. C. Nilsson, and A. Dolling. 1997. Vegetation control by steam treatment in boreal forests: a comparison with burning and soil scarification. Canadian Journal of Forest Research 27:2026-2033.

Nordin, A., J. Strengbom, A. Forsum, and L. Ericson. 2009. Complex biotic interactions drive long-term vegetation change in a nitrogen enriched boreal forest. Ecosystems 12: $1204-1211$.

Orwin, K. H., and D. A. Wardle. 2004. A new index for quantifying the resistance and resilience of soil biota to exogenous disturbance. Soil Biology and Biochemistry 36: $1907-1912$

Orwin, K. H., D. A. Wardle, and L. G. Greenfield. 2006. Context-dependent changes in the resistance and resilience of soil microbes to an experimental disturbance for three primary successions. Oikos 112:196-208.

Peltzer, D. A., et al. 2010. Understanding ecosystem retrogression. Ecological Monographs 80:509-529.

Pfisterer, A. B., and B. Schmid. 2002. Diversity-dependent production can decrease the stability of ecosystem functioning. Nature 416:84-86.

Pickett, S. T., and P. S. White. 1985. The ecology of natural disturbance and patch dynamics. Academic Press, San Diego, California, USA.

Pimm, S. L. 1991. The balance of nature?: ecological issues in the conservation of species and communities. University of Chicago Press, Chicago, Illinois, USA.

Roovers, P., S. Baeten, and M. Hermy. 2004. Plant species variation across path ecotones in a variety of common vegetation types. Plant Ecology 170:107-119.

Sankaran, M., and S. J. McNaughton. 1999. Determinants of biodiversity regulate compositional stability of communities. Nature 401:691-693.

Schimmel, Johnny, and A. Granström. 1996. Fire severity and vegetation response in the boreal Swedish forest. Ecology 77: $1436-1450$

Sørensen, L. I., J. Mikola, and M.-M. Kytöviita. 2008. Defoliation effects on plant and soil properties in an experimental low arctic grassland community - the role of plant community structure. Soil Biology and Biochemistry 40:2596-2604

Tanner, E. V. J., and P. J. Bellingham. 2006. Less diverse forest is more resistant to hurricane disturbance: evidence from montane rain forests in Jamaica. Journal of Ecology 84: $1003-1010$

Tilman, D., P. B. Reich, and J. M. H. Knops. 2006. Biodiversity and ecosystem stability in a decade-long grassland experiment. Nature 441:629-632.

Turetsky, M. R., B. Bond-Lamberty, E. Euskirchen, J. Talbot, S. Frolking, A.D. McGuire, and E.-S. Tuittila. 2012. The resilience and functional role of moss in boreal and arctic ecosystems. New Phytologist 196:49-67. 
Vicente-Serrano, S. M., et al. 2013. Response of vegetation to drought time-scales across global land biomes. Proceedings of the National Academy of Sciences USA 110:52-57.

Walker, J., and P. Reddell. 2007. Retrogression and restoration on old landscapes. Pages 69-89 in L. R. Walker, J. Walker, and R. J. Hobbs, editors. Linking restoration and ecological succession. Springer Series on Environmental Management. Springer, Berlin, Germany.

Wardle, D. A. 1993. Changes in the microbial biomass and metabolic quotient during leaf litter succession in some New Zealand forest and scrubland ecosystems. Functional Ecology 7:346-355.

Wardle, D. A. 1995. Impact of disturbance on detritus foodwebs in agro-ecosystems of contrasting tillage and weed management practices. Advances in Ecological Research 26: $105-185$.

Wardle, D. A. 2002. Communities and ecosystems: linking the aboveground and belowground components. Princeton University Press, Princeton, New Jersey, USA.

Wardle, D. A., K. I. Bonner, and G. M. Barker. 2000. Stability of ecosystem properties in response to above-ground functional group richness and composition. Oikos 89:11-23.

Wardle, D. A., M. J. Gundale, A. Jäderlund, and M. C. Nilsson. 2013. Decoupled long term effects of nutrient enrichment on aboveground and belowground properties in subalpine tundra. Ecology 94:904-919.

Wardle, D. A., G. Hörnberg, O. Zackrisson, M. KalelaBrundin, and D. A. Coomes. 2003. Long term effects of wildfire on ecosystem properties across an island area gradient. Science 300:972-975.

Wardle, D. A., M. Jonsson, S. Bansal, R. D. Bardgett, M. J. Gundale, and D. B. Metcalfe. 2012. Linking vegetation change, carbon sequestration and biodiversity: insights from island ecosystems in a long term natural experiment. Journal of Ecology 100:16-30.

Wardle, D. A., L. R. Walker, and R. D. Bardgett. 2004. Ecosystem properties and forest decline in contrasting longterm chronosequences. Science 305:509-513.

Wardle, D. A., and O. Zackrisson. 2005. Effects of species and functional group loss on island ecosystem properties. Nature 435:806-810.

Wardle, D. A., O. Zackrisson, G. Hörnberg, and C. Gallet. 1997. Influence of island area on ecosystem properties. Science 277:1296-1299.

White, D. C., W. M. Davis, and J. S. Nikels. 1979. Determination of the sedimentary microbial biomass by extractable lipid phosphate. Oecologia 40:51-62.

\section{Supplemental Material}

\section{Appendix A}

Measurements of selected ecosystem properties across the island gradient (Ecological Archives E095-162-A1).

\section{Appendix B}

Results of ANOVA for plant variables, testing for effects of island size and disturbance treatment (Ecological Archives E095-162-A2).

\section{Appendix C}

Results of ANOVA for belowground abiotic variables, testing for effects of island size and disturbance treatment (Ecological Archives E095-162-A3).

\section{Appendix D}

Results of ANOVA for belowground biological and soil activity variables, testing for effects of island size and disturbance treatment (Ecological Archives E095-162-A4).

\section{Appendix E}

Trait values for the three dominant ericaceous plant species present in the study system (Ecological Archives E095-162-A5). 